Fictions of Consent 


\section{RaceBARace}

RACEB4RACE: CRITICAL RACE STUDIES OF THE PREMODERN

Series editors

Geraldine Heng

Ayanna Thompson

A complete list of books in the series is available from the publisher. 


\title{
Fictions of Consent
}

Slavery, Servitude, and Free Service in Early Modern England

\section{Urvashi Chakravarty}

\author{
$\overline{\text { PENN }}$ \\ UNIVERSITY OF PENNSYLVANIA PRESS \\ PHILA DELPHIA
}


Copyright (c) 2022 University of Pennsylvania Press

All rights reserved. Except for brief quotations used for purposes of review or scholarly citation, none of this book may be reproduced in any form by any means without written permission from the publisher.

$$
\begin{gathered}
\text { Published by } \\
\text { University of Pennsylvania Press } \\
\text { Philadelphia, Pennsylvania 19104-4112 } \\
\text { www.upenn.edu/pennpress }
\end{gathered}
$$

Printed in the United States of America on acid-free paper $\begin{array}{llllllllll}10 & 9 & 8 & 7 & 6 & 5 & 4 & 3 & 2 & 1\end{array}$

A catalogue record for this book is available from the Library of Congress.

ISBN 978-0-8122-5365-8 
For Jake and Phineas

And in loving memory of Koli 
